\title{
Structural elements of critical thinking of nurses in emergency care
}

\author{
Elementos estruturais do pensamento crítico \\ de enfermeiros atuantes em emergências \\ Elementos estructurales del pensamiento crítico \\ de enfermeras en emergencias
}

\author{
Maria da Graça Oliveira Crossetti ${ }^{\mathrm{a}}$ \\ Greicy Kelly Gouveia Dias Bittencourt ${ }^{\mathrm{b}}$ \\ Ana Amélia Antunes Limac \\ Marta Georgina Oliveira de Góes ${ }^{d}$ \\ Gislaine Saurin ${ }^{\mathrm{e}}$
}

D0l: $\quad$ http://dx.doi.org/10.1590/19831447.2014.03.45947

\section{ABSTRACT}

The objective of this study was to analyze the structural elements of critical thinking (CT) of nurses in the clinical decision-making process. This exploratory, qualitative study was conducted with 20 emergency care nurses in three hospitals in southern Brazil. Data were collected from April to June 2009, and a validated clinical case was applied from which nurses listed health problems, prescribed care and listed the structural elements of CT. Content analysis resulted in categories used to determine priority structural elements of CT, namely theoretical foundations and practical relationship to clinical decision making; technical and scientific knowledge and clinical experience, thought processes and clinical decision making: clinical reasoning and basis for clinical judgments of nurses: patient assessment and ethics. It was concluded that thinking critically is a skill that enables implementation of a secure and effective nursing care process.

Descriptors: Emergency nursing. Judgment. Nursing process.

\section{RESUMO}

Objetivou-se neste estudo analisar os elementos estruturais do pensamento crítico (PC) do enfermeiro no processo de tomada de decisão clínica. Estudo exploratório, qualitativo, com 20 enfermeiros de emergências em três hospitais do sul do Brasil. A coleta de dados deu-se de abril a junho de 2009; aplicou-se um caso clínico validado, deste os enfermeiros listaram problemas de saúde, cuidados prescritos e ordenaram os elementos estruturais no PC. Na análise de conteúdo, desvelaram-se categorias às quais se relacionaram os elementos estruturais prioritários do PC, a saber: relação de fundamentos teóricos e práticos para tomada de decisão clínica: conhecimento técnico-científico e experiência clínica, processo de pensamento e tomada de decisão clínica: raciocínio clínico e bases para o julgamento clínico do enfermeiro: avaliação do paciente e ética. Concluiu-se que pensar criticamente é uma habilidade necessária para implementar o processo de cuidado de enfermagem seguro.

Descritores: Enfermagem em emergência. Julgamento. Processos de enfermagem.

\section{RESUMEN}

El objetivo de este estudio fue analizar los elementos estructurales del pensamiento crítico (PC) de enfermeras en el proceso de toma de decisiones clínicas. Estudio exploratorio, cualitativo, con 20 enfermeras de emergencias en tres hospitales en el sur de Brasil. La recopilación de datos se llevó a cabo de abril a junio de 2009, se aplicó un caso clínico validado, de esto las enfermeras enumeraron los problemas de salud, cuidados prescritos y ordenaron a los elementos estructurales en el PC. En el análisis de contenido están desplegadas las categorías relacionadas con prioridad a los elementos estructurales del PC, a saber: fundamentos teóricos y prácticos en relación con la toma de decisión clínica: conocimiento técnico y científico y la experiencia clínica, proceso y toma de decisión clínica: razonamiento clínico y bases para el juicio clínico de la enfermera: evaluación del paciente y la ética. Se concluyó que pensar críticamente es una habilidad necesaria para implementar el proceso de cuidados seguros de enfermería.

Descriptores: Enfermería de urgencia. Juicio. Procesos de enfermería. 


\section{口INTRODUCTION}

Critical thinking (CT) is an essential component in the nursing and problem-solving process that should be oriented by standards, policies and codes of ethics. It also involves logic, intuition and creativity, which are equally essential and become stronger with specific knowledge and clinical experience. CT targets safety and quality by focusing on needs of patients, families and the community ${ }^{(1)}$.

Critical thinking is described as an essential elements in the professional practice routine, considering the complexity of healthcare and expressive technical and scientific advancements in the last century that demand the development of cognitive analysis, interpretation and inference skills that help nurses make safe decisions ${ }^{(2-3)}$.

In the $20^{\text {th }}$ century, when the Nursing Process (NP) was incorporated in nursing knowledge, intelligence was identified as an important dimension in the nursing practice, especially in the 1980s when studies on Nursing Diagnosis (ND) and diagnostic accuracy were conducted, both of which supported the development of clinical reasoning ${ }^{(3)}$.

Although this topic has been gaining the spotlight and academic significance since the 1990s, which is the result of studies in different contexts of nursing, critical thinking was born with Modern Nursing founded by Florence Nightingale in the $19^{\text {th }}$ century. The care that was provided, planned and implemented by Florence Nightingale was founded on technical and scientific knowledge, clinical experience and inter-personal skills that helped her make assertive decisions in relation to patients ${ }^{(1,3)}$.

In light of continuous and complex modifications in the healthcare context, critical thinking of nurses allows the provision of safe care insofar as the clinical practice is based on cognitive and logical processes that grant competency and skills to precisely diagnose patients' health problems ${ }^{(4)}$.

The dimensions of critical thinking comprise elements that configure cognitive skills and habits of mind. In addition to these dimensions, behavioural or emotional skills based on attitudes of conscious social and humanist efforts or involvement of the critical thinker with the individual and situation that is under evaluation should also be observed.

These cognitive skills include analysis, application of standards, discernment, search for information, logical reasoning, prevision and transformation of knowledge. Habits of mind are structured around trust, contextual perspective, creativity, flexibility, inquisition, intellectual integrity, intuition, understanding, perseverance and reflection ${ }^{(5)}$. The structural elements were identified in a study that evaluated the opinion of specialist nurses on nursing ${ }^{(6)}$, and concluded that the manifestation of mental habits is evident among nurses that reason in a critical manner, which favours the decision-making process. Clinical decision making as a complex activity that requires both the experience of nurses on priorities when organizing the care environment and use of available information to enable the provision of care ${ }^{(5)}$.

Consequently, CT is defined as a basic competency of nurses to organize the nursing process and solve the problems of patients ${ }^{(2)}$, thus enabling the safe and effective provision of care in different clinical environments ${ }^{(5,7)}$. Given the nature of care in emergency services, decision making must be precise, considering it is a systemic evaluation and judgement process that comprises cognitive and behavioural skills that are inherent to critical thinking ${ }^{(4,8-9)}$.

Based on the premise that structural elements of $\mathrm{CT}$ permeate the clinical practice of nurses, expanded and indepth studies on analysing these elements is therefore justified, within the context of emergency services, to support strategies that enhance this skill in the diagnostic process. It was therefore important to determine which elements of critical thinking are used by nurses during clinical decision making in emergency services. For this reason, the purpose of this study was to analyse the elements that structure critical thinking during the decision-making process of nurses in emergency units of general public hospitals.

\section{$\square$ METHOD}

The presented data was obtained from explanatory, qualitative research conducted at the emergency units of three general and public hospitals in the municipality of Porto Alegre, Rio Grande do Sul, Brazil.

Study participants were 20 nurses selected according to convenience, of which 12 worked in the general hospital's emergency unit, six in the emergency service of a benchmark trauma hospital and two in emergency rooms of a maternity and children's hospital. Criterion for inclusion was: practicing nurse with at least one year of experience in the study field. Nurses that conducted management or administrative roles and who were hired for a probationary period were excluded from the study.

Data were collected from April to June 2009 by means of a questionnaire that was completed by the participants. The first item of the questionnaire included identification, sex, age, academic background, professional background, graduate studies and attendance to permanent education course. The second item presented a problem-situation portrayed as a validated clinical case study ${ }^{(10)}$. The case study was about an elderly man with a medical diagnosis of congestive heart failure who sought assistance due 
to chest pain and shortness of breath, and other relevant signs and symptoms.

Based on this clinical case, nurses had to list the patient's health problems, prescribe nursing care and mention the expected results. After this stage, participants had to list, by order of priority and within a pre-established framework, the first five structural elements of $\mathrm{CT}$ they had used to solve the clinical case ${ }^{(5)}$. The presented structural elements included experience, ethics, technical and scientific knowledge, patient knowledge, patient assessment, logic, teamwork/human resources, material resources, patient assessment instrument and intuition. Then nurses were asked to define the elements they selected.

Obtained data were analysed using the content analysis method $^{(11)}$ that comprises three distinct stages: pre-analysis, exploration of material and treatment of results and interpretation.

The first stage consisted of organizing definitions of $\mathrm{CT}$ elements used by the nurses, which are configured in record units. The second stage consisted of creating categories based on similarity of content and the framework adopted in this study ${ }^{(3-5)}$. The CT elements prioritized by the nurses were associated to these categories. Treatment of these results and interpretation, which is the third stage of content analysis, was conducted using the adopted theoretical framework.

This study complied with the principles of Resolution 196/96 of the National Health Council(12), and was approved by the Research Ethics Committee, registered under number 253/08. All subjects who participated in this study signed an Informed Consent agreement and were identified using numbers to protect their identities.

\section{RESULT AND DISCUSSION}

Collected data allowed the characterization of participating nurses in relation to sex, age, and academic and professional background in the study field. Most of the subject were women (18), with an average age of $32.5 \pm$ 7.5 years. In relation to background, 15 nurses had an academic background of at least eight years and a median of two to six years of experience in the study field.

The characterization of complementary education of nurses showed that 18 had graduate studies in different nursing practice fields and two nurses had master's-level studies. In relation to permanent institutional education courses, those on the Systematization of Nursing Care (SAE) and adult patient care were the most common, attended by eight and four nurses, respectively. Of all the participants, eight nurses had not attended any such courses.

\section{STRUCTURAL ELEMENTS OF CRITICAL THINKING OF NURSES IN EMERGENCY UNITS}

Content analysis revealed three categories that were related to structural elements of CT listed by the nurses: associating theoretical and practical bases for clinical decision making: technical and scientific knowledge and clinical experience; thought process and clinical decision making: clinical reasoning, clinical judgement, intuition, prediction; basis for nurses' clinical judgement: patient assessment, ethics, knowledge of the patient, cultural knowledge, application of normality and ethical standards. These categories and the respective structural CT elements are discussed below, based on the theoretical framework adopted in this study.

\section{Associating theoretical and practical bases for clinical decision making}

Clinical experience and technical and scientific knowledge are essential components and complements to define patient care actions. Clinical experience was defined by nurses as:

[...] associating signs and symptoms to previous diseases. (Nurse 1)

Associating theory and practice. (Nurse 5)

Experience with emergency patients with the mentioned characteristics [...]. (Nurse 9)

Similar situations that occur in all my shifts during my work routine help me recognize the different pathologies. (Nurse 11)

Capacity constructed in time, through daily experiences with patients, to reach excellence in nursing care. (Nurse 18)

Associated to clinical experience, technical and scientific knowledge was defined as being the basis to implement actions, as suggested by other nurses.

Always seek to develop this stage and support our practices. Study groups. (Nurse 4)

[...] literature was used to establish this model (care). (Nurse 7)

Needed to adapt care to the presented signs and symptoms. (Nurse 11) 
Helps to plan nursing practices. (Nurse 12)

Physiopathology helps clinical reasoning, decision making. (Nurse 6)

\section{[...] based on theoretical knowledge/pathologies. (Nurse 14)}

Knowledge and function of physiological standards can be used to build a model based on experiences with patients. (Nurse 18)

Evaluation of the clinical case study provided to the nurses revealed that priorities of clinical decision making are technical and scientific knowledge and clinical experience as elements of CT. The association that participants of this study made between signs and symptoms of diseases and cases of their clinical practice or previous experience with patients that have similar symptoms showed the development of critical thinking for clinical decision making.

From the viewpoint of nurses, clinical experience has a direct relationship with daily work experiences in the emergency units, and helped these professionals to recognize clinical situations and identify the specific care needs of patients.

Similar results were obtained in a study conducted with clinical practice nurses showing that experience and academic background of these professionals was essential to increase critical thinking skills ${ }^{(2)}$.

In the context of professional background, clinical experience was pinpointed and defined by scholars as being an important competency for the development of critical thinking, resulting from knowledge acquired by nurses and their experiences in specific situations of their daily care routine ${ }^{(13-14)}$.

\section{Thought process and clinical decision making}

Analysis and interpretation of the case study allowed nurses from this study to identify and define structural elements that, according to their evaluation, constituted critical thinking and led to clinical decision making: clinical reasoning and clinical judgement, intuition and prediction.

Clinical reasoning and clinical judgement are different, albeit complementary, aspects in the exercise of nurses' evaluations, being that the former leads to judgement, or decision making ${ }^{(13)}$. From these structural CT elements in this category emerged the inter-relation of these elements in the clinical reasoning process expressed in the following statements.

It is thought directed to a problem-situation with the purpose of making the best decision. (Nurse 11)
Clinical history + signs and symptoms + physical exams are part of the assessment process and allow the identification of problems (literal transcription of a participant's statement). (Nurse 14)

The interview, the physical exam, symptoms of the disease are relevant factors that lead to the set of decisions that have to be made in the diagnostic process, which requires clinical reasoning. (Nurse 18)

As a complement to the definitions above, nurse 13 emphasized clinical reasoning and its importance in the context of care.

Necessary to evaluate patients in the short, medium and long term in relation to measures, urgent care, care plans, nursing prescriptions and expected results. (Nurse 13)

Of the critical thinking elements, intuition was described by only one nurse, as follows:

Knowing how to identify possible complications by observing the patient, who directs you to possible problems or situations. (Nurse 11)

Intuition, one of the mental habits of critical thinkers, is defined as the perceptive sensation of knowing without conscious use of reason; immediate knowledge that is not dependant on reasoning ${ }^{(7,15)}$. Intuition, associated to cognitive CT skills, guides nurses when making precise clinical decisions.

\section{Basis for nurses' clinical judgement}

The clinical judgement of nurses was based on the following structural CT elements: patient evaluation, ethics, knowledge of patient, cultural knowledge, application of normality standards.

Technological advancements in healthcare have contributed to the quality of diagnostic and therapeutic processes. However, during patient evaluation, anamnesis and physical examinations are basic instruments of the nursing process $^{(13-14)}$.

Consequently, participants of this study stated anamnesis, physical examination and the application of normality standards as being the structural elements of critical thinking that support the clinical judgement of nurses.

Surveying of information and patient reception. (Nurse 2) 
Important for the construction of anamnesis that will support interventions. I am referring to information such as: Does not take medication, does not follow diet. (Nurse 6)

Helps to plan nursing actions. (Nurse 12)

Anamnesis and physical examinations guide nurses when planning care. (Nurse 13)

Crown-rump evaluation. Observe patients as a whole. (Nurse 15)

Knowing signs and symptoms of the disease through patient evaluations is an important element that guides the prescription of nursing care. (Nurse 18)

To adapt care according to the presented signs and symptoms. (Nurse 19)

Inter-personal, technical and intellectual skills(4) for conducting clinical examinations are essential elements in clinical practice. When evaluating patients, nurses must consider and respect the knowledge and culture of patients, and know how to listen to them ${ }^{(14)}$, which helps to recognize signs and symptoms and their motives for seeking healthcare services.

In nursing care practices, the ability to listen to others is fundamental because it helps to determine the best way to communicate with patients according to their cultural level and knowledge of their health status ${ }^{(14)}$, which was emphasized in the following statements:

Adapt what we say and our actions to their reality and their cultural level. (Nurse 1)

Listening to patients; Identify the difficulties. (Nurse 2)

\section{Professional practices should be ethical. (Nurse 13)}

Clinical judgement was listed and defined by 10 of the 20 nurses in this study, who associated it to adequate investigation of data on clinical histories, the conduction of physical examinations and recognition of signs and symptoms related to the patient's problem. In nursing care, data collection is the first stage of the nursing process ${ }^{(1)}$. The scientific interpretation of these data refers to the identification of nursing diagnoses, which are established in the nurse's clinical judgement and guide the remaining stages of the nursing process ${ }^{(4)}$.

During data analysis, it was perceived that subjects with master's degrees were more familiar with the structural ele- ments of clinical thinking than the others, which is evident in the statement of Nurse 11, and corroborated in a study ${ }^{(2)}$.

Based on the patient's history and evaluation, judgements are made to appropriately plan care. (Nurse 11)

It should be noted that reasoning and clinical judgement, albeit conceptually different, involve cognitive and reflexive mental processes that are associated to previous clinical experiences, which are associated to technical and scientific knowledge that supports this thinking process ${ }^{(13)}$.

Clinical judgements is structured according to the following skills: interpersonal, which involves the ability to communicate, listen and respect opinions; technical, including solid knowledge on clinical evaluation methods and scientific knowledge on health problems; intellectual, which refers to thought processes and the perception skills of nurses in relation to human responses ${ }^{(4,15)}$. The association of these skills helps nurses to make safe decisions and provide qualified care according to the real needs of patients.

Although verbal communication between nurses and patients in emergency environments can be impaired due to the clinical conditions of patients and characteristics of this sector, this process is fundamental when collecting data that will lead to the identification of needs, clinical judgements and the precise planning of care.

Furthermore, the structural elements of critical thinking can also be present in all daily decision making of professional practices that are not directly involved in patient care, but are related to a multi-disciplinary team and management aspects that permeate the organization of complex services such as emergency care.

\section{FINAL CONSIDERATIONS}

The analysis of structural elements of critical thinking defined by nurses of emergency services, in this study, showed that technical and scientific knowledge, patient evaluation, clinical experience, clinical reasoning and ethics were considered priorities by study participants during clinical decision making.

Critical thought is a skill that nurses need in order to improve clinical reasoning and subsequently implement a precise and safe care process.

Study limitations were the need to validate elements that structure $C T$ and their definitions by the nurses that participated in this research. This condition supports the need for future studies on this topic.

Results helped to reveal the importance of critical thinking for clinical decision making. The growing complexity of 
health care in the nurses' practice scenarios demands that nurses use the different dimensions of critical thinking and behavioural and affective skills in the nursing diagnostic process. This is a fundamental presupposition for education, research and care that targets the formation of thinkers with the necessary skills to practice a humanistic profession.

\section{REFERENCES}

1. Alfaro-Lefevre R. Aplicação do processo de enfermagem: uma ferramenta para 0 pensamento crítico. 8. ed. Porto Alegre: Artmed; 2014.

2. Chang MJ, Chang YJ, Kuo SH, Yang YH, Chou FH. Relationships between critical thinking ability and nursing competence in clinical nurses. J Clin Nurs. 2011;20(21-22):3224-32.

3. Kaddoura MA. Effect of the essentials of critical care orientation (ECCO) program on the development of nurse's critical thinking skills. J Cont Educ Nurs. 2010;41(9):424-32.

4. Lunney M. Levantamento de dados, julgamento clínico e diagnósticos de enfermagem: como determinar diagnósticos precisos. In: Diagnósticos de Enfermagem da NANDA: definições e classificação 2009-2011. Porto Alegre: Artmed; 2011. p. 29-42.

5. Facione PA. Critical thinking: a statement of expert consensus for purposes of educational assessment and instruction. Research findings and recommendations. Millbrae, CA: California Academic Press, 1990.
6. Scheffer BK, Rubenfeld MG. A consensus statement on critical thinking in nursing. J Nurs Educ. 2000;39(8):352-9.

7. O'Neil ES, Dluhy NC. Modelling novice clinical reasoning for a computerized decision support system. J Adv Nurs. 2005;49(1):68-77.

8. Crossetti MGO, Bittencourt GKGD, LinckC, Argenta C. Pensamento crítico e raciocínio diagnóstico. In: Silva ERR, Lucena AF. Diagnósticos de enfermagem com base em sinais e sintomas. Porto Alegre: Artmed; 2011. p. 19-33.

9. Paul RW, Healslip P. Critical thinking an intuitive nursing practice. J Adv Nurs. 1995;22(1):40-7.

10. Rubbo AB. Estudos de caso no ensino da identificação de dados clínicos relevantes [dissertação]. São Paulo: Escola de Enfermagem da Universidade de São Paulo; 2002.

11. Bardin L. Análise de conteúdo. Lisboa: Ediç̃es 70; 2011.

12. Brasil. Ministério da Saúde. Conselho Nacional de Saúde. Resolução № 196, de 10 de outubro de 1996. Diretrizes e normas regulamentadoras de pesquisa envolvendo seres humanos. Diário Oficial da União [da] República Federativa do Brasil, Braślia, DF, 16 out. 1996. Seção 1, p. 21082-21085.

13. Bittencourt GKGD, Crossetti, MGO. Habilidades de pensamento crítico no processo diagnóstico em enfermagem Rev Esc Enferm USP [Internet] 2013 [mentioned in 04 jan 2014];47(2):341-7. Available in: http://www.ee.usp. br/reeusp

14. Lunney M. Pensamento crítico para o alcance de resultados positivos em saúde: análises e estudos de casos em enfermagem. Porto Alegre: Artmed; 2011.

\section{Author's address:}

Marta Georgina Oliveira de Góes

Av. Jerônimo de Ornelas, 688, ap. 602, Santana

90040-340, Porto Alegre, RS

E-mail:mgogoes@gmail.com
Received: 26.03.2014

Approved: 03.09.2014 